Bond University

Research Repository

\title{
A decade of service-learning: A review of the field ten years after JOBE's seminal special issue
}

Kenworthy-Uren, Amy

Published in:

Journal of Business Ethics

DOI:

10.1007/s10551-007-9549-3

Licence:

Other

Link to output in Bond University research repository.

Recommended citation(APA):

Kenworthy-Uren, A. (2008). A decade of service-learning: A review of the field ten years after JOBE's seminal special issue. Journal of Business Ethics, 81(4), 811-822. https://doi.org/10.1007/s10551-007-9549-3

\section{General rights}

Copyright and moral rights for the publications made accessible in the public portal are retained by the authors and/or other copyright owners and it is a condition of accessing publications that users recognise and abide by the legal requirements associated with these rights.

For more information, or if you believe that this document breaches copyright, please contact the Bond University research repository coordinator 


\section{Bond University}

\section{ePublications@bond}

9-1-2008

\section{A decade of service-learning: A review of the field ten years after JOBE's seminal special issue}

Amy L. Kenworthy-U'Ren

Bond University, akenwort@bond.edu.au

Follow this and additional works at: http://epublications.bond.edu.au/business_pubs

Part of the Business Law, Public Responsibility, and Ethics Commons

\section{Recommended Citation}

Amy L. Kenworthy-U'Ren. (2008) "A decade of service-learning: A review of the field ten years after JOBE's seminal special issue" ,, .

http://epublications.bond.edu.au/business_pubs/150 


\section{A DECADE OF SERVICE-LEARNING:}

A REVIEW OF THE FIELD TEN YEARS AFTER JOBE'S

SEMINAL SPECIAL ISSUE

- Categorized as a “Teaching Business Ethics” submission for reviewing purposes.

- Keywords:
o Community Engagement
o Review of the Field
o Service-learning
o Teaching Business Ethics 


\begin{abstract}
This paper reviews developments in the field of service-learning, both in terms of general management education and business ethics specific courses, over the past ten years. Using the 1996 Journal of Business Ethics special issue on service-learning as a benchmark, numerous accomplishments are presented and continued barriers are discussed. Finally, three issues are raised as next steps for service-learning authors and practitioners as we move forward into the next decade: (1) designing effective and sustainable university/community partnerships, (2) addressing problems stemming from the conspiracy of courtesy, and (3) optimizing the intersection between online learning and service-learning.
\end{abstract}


Just over ten years ago, in January 1996, the Journal of Business Ethics (JOBE) published a special issue guest edited by Denis Collins and titled “Community Involvement and Service Learning Student Projects.” At that time, the JOBE special issue was a first-of-its-kind in the business education domain. No other editorial board for journals in the management sciences had so clearly recognized, and acted upon, the emergence of service-learning as a teaching tool.

\section{The 1996 Journal of Business Ethics Special Issue}

Thanks to Denis Collins and the editorial team, the 1996 special issue was not only ground-breaking, it was comprehensive. Authors included service-learning experts, business faculty, and university program administrators. The articles were both conceptual and descriptive, spanning every level of service-learning integration, including course-specific, program-specific, institution-specific, and national (U.S.A.). The lead article was an introduction and overview of the special issue; the final article, published at the end of the issue, was a critique of the nine servicelearning projects and programs that were profiled in the issue. In this critique, Thomas Kolenko, Gayle Porter, Walt Wheatley, and Marvelle Colby (1996), faculty members from four different U.S. institutions, summarized the strengths and challenges they saw for business education generally, and business ethics courses specifically, as the field began to move forward with service-learning into the $21^{\text {st }}$ century. They raised the concern that business students were learning in a world that was rife with examples of ethical lapses on the part of business leaders. As the authors may have guessed, the last decade has proven to be no different, with staggering examples of unethical business practices taking place during the late 1990s 
and early 2000s. As the authors so aptly stated in their article written over a decade ago:

“No doubt major ethical lapses and challenges to business icons in the 1980s caused schools of business to expand student developmental goals at the intrapersonal level. Formal coursework in business ethics, responsibilities of leadership, and business and society have been installed and almost universally adopted, especially in AACSB accredited schools. Faculty charged with teaching these courses have found a need to go beyond just establishing cognitive and moral awareness of societal issues in students to truly make a difference” (1996: 134).

In their article Kolenko and his colleagues described three components of service-learning experiences: (1) personal insight, (2) application of skills, and (3) understanding social issues. They argued that, to varying degrees, the three components were all incorporated into each of the nine programs described in the special issue. They also described a number of barriers to service-learning integration. These included: (1) faculty resistance, (2) unsuccessful and/or negatively perceived project or program outcomes, (3) workload issues, (4) selfish "limelight” issues on the part of involved faculty, (5) insufficient institutional support, (6) liability issues, (7) student resistance, (8) personal agendas for faculty, and (9) on-site resistance from community organizations. Now, a decade later, it is time to revisit the 1996 JOBE special issue on service-learning to see just how far we have come.

In this article, I recount what has happened over the past decade with respect to service-learning in business education, both in terms of general management education and, specifically, business ethics courses. Using that review as a 
foundation, I suggest that Kolenko et al.'s (1996) three components are still applicable to service-learning projects. I also address each of Kolenko et al.’s barriers to servicelearning as they apply to faculty who are interested in using the teaching tool in

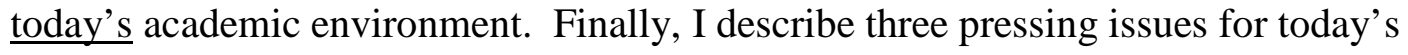
service-learning - while these issues apply to all business educators, I suspect the charge will initially be accepted by those of us who teach business ethics, as it was in the mid-1990s with the JOBE special issue.

\section{Service Learning: An Overview of the Past Ten-Years}

At a universal level, across all disciplines in higher education, our understanding and application of service-learning have clearly progressed over the past decade. For starters, consensus is growing about the conceptual and literal approaches to the term “service-learning.” The 1996 JOBE special issue illustrates the disparities that existed in the field ten years ago. In terms of the literal use of the term service-learning, in the 1996 special issue, only one third of the authors hyphenated the words "service” and "learning," one third did not hyphenate the term, and one third did not use the term at all. Today, most academic scholars and practitioners agree that the term should be hyphenated as a visual representation of what service-learning actually is. As Barbara Holland, Director of the U.S. National Service-Learning Clearinghouse, described in a recent interview, "Service-learning is all in the hyphen. It is the enrichment of specific learning goals through structured community service opportunities that respond to community-identified needs and opportunities.” (Kenworthy-U’Ren, Taylor, and Petri, 2006: 121). 
A shared conceptualization of the term service-learning has helped with the issue of credibility. One significant difference between 1996 and today is the academic credibility associated with the practice of service-learning. Today, servicelearning is seen as a legitimate and viable teaching tool for use in university educational environments (Hartley, Harkavy, and Benson, 2005). This credibility has pushed the field to move beyond conceptual descriptions and anecdotal evidence to generate concrete outcomes through empirical studies. Over the past decade, a large number of empirical articles have added to the literature on the measurable outcomes of service-learning initiatives (Bringle, Phillips, and Hudson, 2005). Engagement in service-learning projects has been shown to increase students' commitment to service (McCarthy and Tucker, 2002), preparedness for careers (Gray, Ondaatje, and Fricker, 2000), personal growth, self-esteem and personal efficacy (Primavera, 1999), communication skills and social issue awareness (Leung, Liu, Wang, and Chen, 2006), citizenship (Lester, Tomkovick, Wells, and Flunker, 2005), and commitment to social justice and social change (Roschelle, Turpin, and Elias, 2000).

Regarding integration into higher education, the past decade has seen the wide-spread emergence of service-learning as a teaching tool used across a variety of disciplines, educational levels, and universities around the world. In terms of disciplinary diversity, the current Campus Compact website (www.compact.org) showcases over 300 “exemplary” service-learning syllabi from 48 different disciplinary domains ranging from anthropology to urban planning. Regarding tertiary educational program levels, service-learning projects have been recorded in undergraduate, graduate, and executive subjects with a variety of operational frameworks (e.g., required versus elective, one-time placement versus semester-long 
immersion, individual exercise versus group project, grounded in a single subject versus application and integration into a subject "cohort”).

On the international front, service-learning is expanding at a rapid pace. With practical roots embedded in American educational initiatives linking civic engagement to higher education (Ryan, 1997), today’s service-learning programs, forums, and summits are taking place in countries including Argentina, Australia, Brazil, Canada, Germany, India, Ireland, Italy, South Africa, Spain, Taiwan, and Thailand. The international practice of service-learning has spawned a recent emergence of published articles describing university programs run with non-U.S. students in non-U.S. countries (the author is intentionally excluding U.S.-based study abroad service programs as they are, in effect, U.S. programs). International program examples include a training program for undergraduate and postgraduate students based in a Faculty of Humanities in South Africa (Roos, et al., 2005), an undergraduate democratic citizenship program in Britain (Annette, J., 2003), a teambased general education program for undergraduate students in Hong Kong (Ngai, S., 2006), and a strategic planning non-profit consulting project run with graduate students in Holland (van der Voort, Meijs, and Whiteman, 2005). As a testament to the international expansion of service as a learning tool applicable at all educational levels, the Tokyo (Japan) metropolitan government approved a service requirement for students in the city’s approximately 200 high schools to begin in 2007 (Cavanagh, 2005).

As a scholarship-driven cross-disciplinary indicator of service-learning's emergence, in 2001, the Michigan Journal of Community Service Learning, a U.S. national peer-reviewed journal with a specific focus on service-learning, doubled the number of issues it publishes each year due to increasing demand. At a management 
domain specific level, the Annual Meeting of the Academy of Management has had service-learning symposia, forums, and/or paper presentations every year since 1997. The scholarship of service-learning in management education has slowly followed JOBE's lead. In 2000, Paul Godfrey and Edward Grasso edited a book, as part of the American Association for Higher Education's (AAHE) series on service-learning in the disciplines, titled Working for the Common Good: Concepts and Models for Service-Learning in Management. In September of 2005, the Academy of Management Learning and Education published a special issue on service-learning in management. In June of 2006, the International Journal of Case Method Research and Application published a special issue on service-learning, focused on the application of service-learning as a tool for business educators to use to create 'living' cases. In April of 2007, the Journal of Management Education, released a call for papers focused solely on articles describing exemplary "how to" practices for servicelearning projects and programs. Finally, in 2008, the International Journal of Organizational Analysis will publish a special issue on service-learning.

During the past decade (1996-2006), the literature in business ethics, as a specific subset of business and management education, has maintained a constant stream of service-learning oriented articles. Representative examples include:

- In a 1997 article about service-learning in JOBE, Marilynn Fleckenstein convincingly suggested that "a service-learning pedagogy would be one way to educate the business student in ethics. An integrated service project stressing rights and responsibilities could create a feeling of what it means to be a member of a community and would emphasize the importance of social involvement” (1997: 1347). 
- In 1999, Beverly Kracher published an article in Teaching Business Ethics (now part of JOBE), within which she outlined eight steps for integrating service-learning into business ethics courses. She used service-learning as a tool to encourage action in her business ethics courses, arguing that "a business ethics course must prepare students for ethical business action” not just ethical decision making (1999: 293).

- In 2000, Paul Godfrey published a chapter in the AAHE Management volume mentioned above, arguing that service-learning "represents a strategy for helping the private sector maintain the moral authority to set the social agenda” (2000: 38).

- In 2002, Colette Dumas published an article in the International Journal of Value-Based Management where she described how service-learning initiatives bridged the gap between traditional curricular content and the needs of today's societies. She argued that service-learning helps to prepare students to be "lifelong learners and active, caring participants in their communities” (2002: 249).

- In 2003, Gina Vega and Mary Ann McHugh published an article in the Journal of Academic Ethics, where they described a course called "Managing Corporate Ethics” involving a semester-long service-learning project with four senior citizen centers in the local community. The authors wrote about the strengths, weaknesses, and learning outcomes of the ethics project in detail; in the end, they stated "we believe that this project was worthwhile. It met our academic goals, it provided a valued service, it provided an experiential learning opportunity for students who might not other wise have been 
involved in one, and it cemented relationships between the institution and the community” (2003: 114).

- In 2004, Denis Wittmer published an article in JOBE describing the results of a survey of students who had participated in service-learning at the University of Denver through an ethics-based MBA core course called 'Values-Based Leadership.' Forty-eight percent of the students reported an “increased recognition of the level and kinds of needs that exist" in the community, $46 \%$ reported an "increased awareness of how individuals and businesses are involved in professional service," and 35\% of students reported a "realization of personal satisfaction for community service activity” (2004: 365).

- In a 2006 issue of JOBE, James Weber described the development, integration, and promotion of an organizational ethics program at the Duquesne University schools of business. In a review of tools used to increase students' understanding of ethics, the second most common tool for integrating ethics into courses, as reported by faculty at the schools, included involvement in a community service activity. In fact, one of the recommendations of the schools' collective review was to more actively support faculty members "by placing students in community service opportunities related to their disciplines, such as accounting students helping the elderly complete their tax forms, or marketing students educating at-risk consumers” (2006: 33).

\section{$\underline{\text { Kolenko et al's Three Components }}$}

As mentioned above, the three components of service-learning experiences identified by Kolenko and colleagues in their 1996 article are: (1) personal insight, (2) 
application of skills, and (3) understanding social issues. In this article, the authors agreed that each of the components was applicable to the nine service-learning programs described in the special issue. Ten years later, do these components still apply? I argue the answer is yes.

In support of my response, I turn to another set of scholars in the servicelearning domain. Paul Godfrey, Louise Illes, and Gregory Berry (2005) recently published a paper in which they argued that service-learning projects created much needed breadth in business education programs. "Service-learning pedagogy seeks to balance academic rigor with a practical relevance, set in a context of civic engagement, which furnishes students with a broader and, we argue, richer, educational experience” (2005: 309). In their article, they highlight three elements for successful service-learning experience, or what they have termed the "3 Rs" - Reality, Reflection, and Reciprocity.

The first R, Reality, is closely aligned with Kolenko et al's personal insight. One of the most salient criticisms of business education today is the absence of realistic experience, applied learning, and grounded personal development (Mintzberg \& Gosling, 2002; Pfeffer \& Fong, 2002). Service-learning experiences place students in real-world situations where they address real-world needs. The level of personal insight that students typically experience is a direct result of the fact that servicelearning projects challenge students to solve problems with no right answers and realworld consequences. Personal insight and development is the most predictable outcome for service-learning students, based solely on the uniqueness of the reality of the learning task and context.

The second R stands for Reflection. Reflection is a central tenet of any service-learning program; it is the hyphen Barbara Holland was referring to, 
connecting the service with the learning. Reflection is the tool through which students take their application of skills, Kolenko et al's second component, and translate it into knowledge. The final R, Reciprocity, is how students learn about and come to understand social issues, Kolenko et al's third component. If service projects are not grounded in reciprocity, and only consist of a one-way give and take process, then it is unlikely that students will learn the realities of the social situations they are engaged in. If reciprocity is one of the principles upon which the service experience is founded, then students and community members should both understand and embrace the idea that their relationship is about mutual learning - the experience is about the creation of a partnership, with intended mutually beneficial outcomes.

The similarity between Kolenko et al.’s (1996) components and Godfrey et al.’s (2005) elements is not surprising. At a functional level, service-learning has some very basic tenets that if executed well will provide high-quality and real-world based learning experiences for students. With an increasing number of university educators using service-learning, and continued support for the teaching tool through anecdotal evidence and empirical examination, we do not need to reinvent the figurative service-learning wheel. The basic tenets of successful service-learning projects have been in place for over a decade, our challenge today is to retain these tenets as we move through our rapidly changing educational landscape. The good news is that this is happening... we are moving forward.

\section{$\underline{\text { Kolenko et al's Barriers }}$}

In their 1996 summary article, Kolenko et al also identified nine barriers to successful service-learning integration. These included: (1) faculty resistance, (2) unsuccessful and/or negatively perceived project or program outcomes, (3) workload 
issues, (4) selfish "limelight” issues on the part of involved faculty, (5) insufficient institutional support, (6) liability issues, (7) student resistance, (8) personal agendas for faculty, and (9) on-site resistance from community organizations. Of the nine barriers, I argue that two of them clearly remain with us today, two of them are almost entirely gone, and five of them have significantly reduced over the past decade.

I argue that two of the barriers have not changed much over the past decade: workload issues and personal agendas for faculty. With respect to workload issues, there is no doubt that service-learning projects are more work than traditional lecturebased classes (Fritz, 2002; Papamarcos, 2005). Service-learning is a time and resource intensive teaching tool. While the level of work appears to be universally recognized, to date little has been written about educational policies reflecting the workload differential. Most of the scholarship in the area focuses on the intrinsic value of the increased workload outcomes for faculty (e.g., heightened student learning, personal satisfaction). This is not to say that universities have not increased their institutional focus on service-learning over the past decade; they have.

However, even for faculty working in institutions with newly created service-learning centers and other support mechanisms, the real-world, fluid, and often chaotic nature of service-learning projects means that the workload will invariably be higher for service-learning courses than it is for traditional classroom-based methods.

The second barrier that exists as it did a decade ago is the liability of faculty members' personal agendas. When faculty members have personal agendas to help a particular community-based organization or issue (e.g., a faculty member who sits on the board of a local non-profit organization and who blindly designs projects with that organization regardless of issues related to the project's fit in the course), the potential exists for a faculty member to let his or her passion override thorough preparedness 
and effective communication with students. Strong personal agendas may blind faculty to ineffective project integration into a course. In instances where this happens, students and community organization members will see the lack of preparation and integration, increasing the chances of project failure. As with any experiential learning project, laying a foundation for how and why theory should connect to practice is a requisite first step for project success and heightened student learning.

Two of Kolenko et al's barriers have been dismantled over the past decade. The relative absence of one of the barriers, liability issues, is a direct result of the prevalence of service-learning in all levels of education today. Most, if not all, universities have liability insurance for any organized student activities that take place outside of a university’s walls. There may be some international variation in this area, but there is certainly precedence for liability coverage. Interested faculty should simply check with their university administrators to ensure that this protection is in place. The second barrier that has all but disappeared is the potential for one negative course experience to result in university-wide resistance to service-learning. Servicelearning is so well enmeshed in the U.S. national educational agenda and in most institutions, typically because of its ability to meet university-wide mission statements (community engagement, citizenship, social responsibility, values- and ethics-based learning experiences), that one bad experience no longer has the power to override its inclusion. In the past, when university members were first getting introduced to this teaching method and individual course-based trials were unique at institutions, one bad experience was salient. Today, there are a multitude of service-learning data points at most institutions, with many of them from courses that have been running service-learning projects for a few years or more. In today’s educational 
environment, with the vast array of service-learning resources available, one would hope that the bad experience data points would be the outliers in a large data set of service-learning projects and programs.

There are five remaining barriers from Kolenko et al's original list; each of which has significantly reduced over the past decade. The first two are institutional support and faculty resistance. As stated above, service-learning projects embody much of what it is universities say they do in their mission statements. Supporting the dissemination of service-learning at the institutional level makes sense. An example of increased institutional support across all schools and disciplines can be seen at the University of Missouri at Kansas City (UMKC). In a description of the UMKC's institutional changes, Connie Beachler and colleagues (2006) state the following, "In 1999, in response to the national, and local, criticism of higher education, UMKC faculty and administrators began an extensive strategic planning process. Over the next seven years, the university initiated significant changes. These changes are helping reshape UMKC's culture as it embraces its mission as an urban university, to be proactive in its responsiveness to its community. A major part of the campus-wide change was the 2001 initiation of the UMKC Center for the City (C4C) and its AS-L program, Students in the City (SITC)” (2006: 160). Another recent example, with a primary focus on business students, is seen in Steinberg et al's (2006) description of the University of Hartford’s MBI program. Through the MBI, students from a wide range of business disciplines work with the local community through a university-run micro-business incubator economic development program. Both of these examples illustrate the increases in institutional support that have taken place over the past decade. One of the positive outcomes of institutional support for programs or initiatives is often faculty acceptance and adoption. 
With more faculty “doing” service-learning, there has been an increase in the number of benchmarks at the local, regional, national, and international levels. With additional examples of successful projects in place, reducing the need for faculty to “create the service-learning wheel,” faculty may have less resistance than they had before to give service-learning a try. The additional benefit of increased institutional support and visibility for this method is that scholarship in this domain is more common than it was ten years ago. As can be seen in the variety of business ethics journals listed above, outlets for faculty publication in this area have dramatically increased over the past decade. Increased outlets for publishing is another factor supporting decreased faculty resistance, as scholarship allows for the higher workload to be leveraged into tangible rewards (i.e., conference presentations and publications). Increased participation and scholarship opportunities have significantly reduced another of the barriers - the faculty limelight issue. In 1996, Kolenko et al. wrote about the barrier of faculty members who were reluctant to share the service-learning limelight with others in their institutions. These faculty members were most likely their institution's first-movers. With the dramatic increase in the use of servicelearning across all faculties and schools in universities, having only one person who “owns” service-learning would be a detriment to institutional success in today’s environment.

The reduction of the last two barriers is also, at least partially, due to the increased prevalence of service-learning at all educational levels (K-12 and university-level). The last two barriers identified by Kolenko and colleagues are student and community organization resistance. Regarding the decrease in student resistance, as service-learning becomes a teaching tool that is embedded at all institutional levels, students become increasingly familiar with what it represents. 
The U.S. is at the forefront of this movement. As of 1999, The U.S. Department of Education found that $46 \%$ of public high schools and $38 \%$ of public middle schools offer service-learning opportunities (www.servicelearning.org). And, as of early 2006, Campus Compact (a coalition of university presidents dedicated to universitybased civic engagement) had over 950 member colleges and universities, representing approximately 5 million students participating in service-learning initiatives (www.compact.org); this number represents an extreme increase from Campus Compact's 4 member institutions in 1985. With such a dramatic increase in the number of young people who engage in service-learning before they enter university, service-learning may well be an academic expectation for many of today's university students.

The final barrier that is slowly becoming dismantled is community organization member resistance. While the goals of service-learning projects are supposed to be reciprocal in nature, there have certainly been one-sided exceptions to that rule. In the past, it was not uncommon for service-learning projects to be designed with an almost exclusive one-sided focus, for the benefit of the academic partners (i.e., students and institutions). This design stems from the old "server and served” mentality, where the academy was seen as the server and the community organization(s) seen as the served (DiPadova-Stocks and Brown, 2006). As a result, some community organizations had become disinterested in service-learning partnerships - the resources required for long-term partnership investment were simply not viable given the resultant gains (Bushouse, 2005). Today, service-learning is conceptualized and practiced with a strong focus on reciprocity, partnership, and mutual learning (Enos and Morton, 2003). As this new approach pushes out the old 
one, and as community partners are increasingly engaged as partners in the learning process, community organization member resistance should continue to dissipate.

In summary, there has been a great deal of progress in the service-learning domain over the past decade. While the basic tenets of service-learning programs remain the same, many of the barriers to integration have been either significantly reduced or eliminated. This progress is due to a large groundswell of application, evaluation, and support for service-learning in higher education. We now know enough about service-learning that we can collectively share best practices with interested faculty. One example of this, specific to the business domain, is the "WE CARE” approach (Kenworthy-U’Ren \& Peterson, 2005). This approach specifies six criteria for effective service-learning initiatives: they should be $\underline{\text { Welcomed by faculty }}$ members, Evidence-based as a result of thorough preparation and integration into a

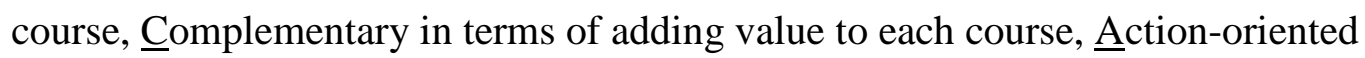
involving students in tangible real-world projects with associated goals and outcomes, Reciprocal in nature, and Epistemic with the aim of increasing students' cognitive abilities. Another approach, advocated by Dumas (2002), is the four-step “preparation, service, reflection, and celebration” method of designing servicelearning projects. Dumas (2002) believes that faculty members should carefully prepare the service-learning components of their courses through communication with involved community members and clear identification of related theory and associated learning outcomes. Students perform “challenging, engaging, and meaningful” service (p.252) and reflect on their experiences both during and after their service work. Finally, an appropriate celebration should be held to mark the contributions and achievements of all involved parties. 
Again, we see similarities in the two approaches above. Both of them are about designing effective learning-based connections between student experience, course content, and community. With numerous examples of this type of best practice available, coupled with heightened awareness of the positive outcomes associated with service-learning, calls for educational reform, and institutional and national support, I believe service-learning will continue to be an increasingly utilized tool for learning in higher education.

\section{Service-Learning: Three Issues for Today and Tomorrow}

As is the case in life and good fiction novels, with every new chapter comes a new issue to resolve. The decade that lies in front of us is a new chapter for servicelearning in business education. With the new chapter's inception have come three interrelated areas that are in need of conceptual, scholarly, and practical attention: (1) developing effective partnerships, (2) addressing the conspiracy of courtesy, and (3) online learning as it impacts service-learning practice.

\section{Effective Partnerships.}

In the section above describing changes to barriers for service-learning, I discussed the slow but steady shift in the conceptual understanding of what university and community organization partnerships should be. The one-sided academic institutional focus is shifting, but not as quickly or as effectively as it should. This is partially due to the siloistic and hubristic nature of the academic enterprise. As academicians, we are trained to become experts in a field. Expertise is a doubleedged sword in the educational domain, particularly in today’s learner-centered 
university context - the context of which service-learning is a part. This learnercentered approach requires a redefinition of the role of a faculty member, away from that of a knowledge provider toward one of a knowledge creator (Freed, 2005; Ramsey, 2002; Ramsey \& Fitzgibbons, 2005). It requires faculty members to not only redefine themselves but also redefine their environments. Classroom interactions become less predictable, with student-directed shifts in material and pace creating unexpected and unplanned interactions (Kunkel, 2002; Wheeler \& McLeod, 2002). To achieve this shift is critical to the success of service-learning. Servicelearning partnerships are only possible in learner-centered environments, where faculty members are engaged partners in the learning process - partners with their students and involved community members.

Effective learning-oriented partnerships are not easy to create. Not only do they require faculty member shifts in role and classroom environment, they also require trust and involvement from the partner organization. Oftentimes, this is not an easy task. Fist, universities are notoriously inaccessible for most community members. The untouchable "ivory tower" mentality still prevails in many community members' mindsets. Second, most faculty members were not raised in the local community surrounding their universities. Faculty tend to move to locations based on job availability and, as a result, have few, if any, contacts with local community organizations. Third, community organizations are, by nature, organizations. Administrators in community organizations have very real resource constraints as well as numerous real-time issues to resolve. As difficult as it is for many faculty members and university administrators to accept, community organizations may neither be interested nor have the time to invest resources in long-term servicelearning partnerships. In fact, in an examination of community organization 
members' interest in university partnership programs, Bushouse (2005) found that, because of resource constraints (e.g., staff time), well over half (64\%) of the organizations she sampled were only interested in transactional or "one-time only" projects which do not require much investment on either party's part. The remaining $36 \%$ of the organizations, or only just over one third of them, were open to longer term, more sustained engagements.

Dorado and Giles (2004) also looked at the issue of sustainable and effective university/community partnerships. Using a combination of their combined decades of personal experience with service-learning as well as information derived from 27 interviews with members from 13 community partner organizations, they took a different approach to Dumas, they wanted to define the different types of engagement. Their goal was to create a common language of intent and interest for university and community partners. They presented three 'paths of engagement' for university and community service partnerships: tentative, aligned, and committed. Tentative engagements are those where "learning behaviors are dominant" and "partners are not interested in building a sustainable relationship” (p.30). Engagements are aligned when partners "seek to create a better fit between their goals" (p.31); this tends to be a short-lived path, as organizations either transition to a committed partnership or dissolve their relationship. Finally, the committed path of engagement represents partnerships with "actions and interactions that denote that partners value the partnership beyond the departing project” (p.31). For most faculty members and institutions, tentative engagements will be the first step. If the project(s) is wellplanned, effectively communicated, and monitored for quality throughout, then the goal of a future sustainable long-term committed partnership may well be attained. 
In this paper, I challenge the field to use Dorado and Giles’ (2004) understanding of the different types of partnerships to move beyond the use of simple, short-lived, and disposable partnerships toward that of institutional-level committed engagement. We encourage our students to become interested, thoughtful, and active members of their businesses, communities, and societies, yet many institutional programs do not effectively model the way. The presence and commitment to effective and sustainable partnership programs with community organizations is a demonstrable measure of a university’s successful engagement. In creating this type of engagement, we begin to "walk the talk" of social responsibility and sustainable development. We also begin to at least partially address Galbreath’s (2006) concern that, as academics, we are overly obsessed with economic performance indicators of firm success and we are passing that ignorance on to our students and communities.

\section{Conspiracy of Courtesy.}

The second related area in need of attention as we move forward with servicelearning is to understand and address the conspiracy of courtesy (DiPadova-Stocks \& Brown, 2006). As described by DiPadova-Stocks and Brown (2006),

"Service-learning as a field has yet to confront the necessary reciprocity issues involved in service, (we argue) that service-learning can benefit from the experience of people who lead humanitarian organizations. Humanitarian work provides needed service while identifying the strengths of those being served, and developing their assets — or resources. When embarking on the task of providing service to others, it is important to candidly discuss and clearly define the goals and expected outcomes. The "conspiracy of courtesy" interferes with the candid quality of interaction... The conspiracy reinforces 
service providers’ presumptions of their own knowledge about what others need. This conspiracy denies providers important accurate information about the recipients' situations. Without this firsthand knowledge from recipients about their situations and desires, service providers may fail to recognize the strengths of those being served” (p. 137-138).

DiPadova-Stocks and Brown (2006) argue that there are three assumptions underlying the conspiracy of courtesy. First, that educationally qualified academics possess all of the relevant knowledge to assist people in need. Second, that there is little knowledge academics can acquire from community members in need. Third, and finally, that people in need lack appropriate levels of strength and resources. As DiPadova-Stocks and Brown (1996: 138) state, “Acceptance of these foundational assumptions prevents acknowledgment, confrontation, and disarmament of the conspiracy.”

If service-learning is going to live up to its promise, as a tool uniquely designed to increase students' awareness and the scope of their learning while providing long-term and sustainable change in our communities, then we need to carefully engage in its adoption and implementation. As stated above, servicelearning is not easy. It requires passion and perseverance. It takes more time and energy than traditional classroom experiences. It requires change on the part of most faculty members, both in terms of personal approach and classroom environment. It takes acknowledgement that there are often no right answers, rather, information retrieval and processing is partial, biased, and often disjointed. Service-learning challenges us to rethink what our roles as educators are, both in terms of our university and our community citizenry. It also challenges us to examine our fears, biases, and strengths. 
One of the difficulties of service-learning is the fact that it requires commitment and involvement from multiple stakeholders. These stakeholders include faculty members, students, and community organization representatives. For servicelearning projects to be successful, all of the involved members must understand themselves as they collectively work toward mutual learning outcomes. To understand oneself is only the first step, as was highlighted in the discussion above about community member resource constraints; aligning the needs of three parties with various priorities and interests is often an arduous, yet imminently attainable and rewarding, task.

\section{Online Learning.}

The process of implementing effective service-learning programs becomes increasingly complex when another factor is added in - today’s online learning environment. For many institutions, online learning is not a vision for the future, it is the reality of today. Online learning is an integral part of today’s organisational (Shea-Schultz \& Fogerty, 2002) and educational environments (Alavi \& Leidner, 2001). Yet, for many of us who are engaged in the practice of online learning, there is a paucity of information about not only how to do it well but also its effects on student learning and engagement (Brower, 2003). In fact, as Arbaugh (2005) pointed out in a recent review of research in this area, conceptual and empirical scholarship in online learning first emerged as published work as late as 1999-2000.

With the educational environment rapidly shifting to an electronic medium, it stands to reason that in the near future a growing percentage of service-learning projects will be run online. As a testament to this shift, and to the impending intersection between service-learning and virtual classrooms, Amber Daily, Emily 
Donnelli, and Laurie DiPadova-Stocks are editing a cross-disciplinary book titled “Service eLearning: Educating for Citizenship” due for publication in late 2007.

With the question of how to effectively integrate service-learning and online learning facing us today, I recommend following Taylor's (2003) advice on faculty training. She states that faculty training is one of the critical keys to progression in online course development. In fact, she goes beyond simply recommending training to advocate a multi-disciplinary and online approach to faculty development, providing authentic experiences for educators as online students themselves. This certainly fits with part of the mission of service-learning, to create experiences where “student-centered learning communities” are created (Clark, 2001; Poole 2000). This type of learning community is characterised by fluid and co-created learning processes where the faculty member is no longer an information provider, but a facilitator and member in the process of knowledge creation. Faculty members who participate in online service-learning experiences as partners in the process will be the scholars who lead the rest of us forward as we enter the new online world of servicelearning practice. It is a complex issue we can not afford to ignore.

\section{Conclusion}

The overall goal of this paper was to review the past decade in terms of service-learning's development and growth in management education, with a specific emphasis on business ethics, and to highlight some of the issues that remain for practitioners who use this teaching tool. Collectively, we have witnessed significant change in our academic environments; teaching today is about real-world, integrated, and enhanced learning. We are no longer expected to teach in disciplinary silos. 
Today, we are asked to work together, with each other and our communities, to create an educational environment that more clearly reflects our constantly changing personal, social, and organizational lives. Service-learning can do just that. Servicelearning, if conceptualized and operationalized well, has the potential to change our students' educational experience. Through service-learning, students work with and learn from community organizations - they become partners in real-world positive change.

With all of its inherent challenges, at the operational, structural, interpersonal, and intrapersonal levels, service-learning is an incredibly powerful teaching tool. Service-learning provides opportunities for students to expand themselves through interactions with diverse others (Brody \& Wright, 2004), more closely examine and understand social problems (McCarthy, 1996), and create long-term and sustainable positive change in the communities of which they are a part (Papamarcos, 2005).

As the world progresses, so too do our students, our classes, and the educational experience. Service-learning allows us, as educators, to move forward as essential links in the development of society. With the next decade in front of us, we have challenges to address, communities to partner with, students to interact with, and an unlimited world of learning to explore. We have made great strides over the past decade, particularly with respect to academic credibility, empirical research, behchmarking best practice, and sustainability. For the next decade, we have at least three major issues in front of us - effective partnering, the conspiracy of courtesy, and service-learning in online environments.

I look forward to following the progress of service-learning, both in terms of general management education and business ethics specific education, over the next 
A Decade of Service-learning

ten years. As the last decade has shown, there is no limit to what we can achieve as long as we work together in constructive and collaborative ways. 


\section{REFERENCES}

Alavi, M. and Leidner, D.E.: 2001, 'Research commentary: Technology-mediated learning - A call for greater depth and breadth of research', Information Systems Research 12(1), 1-10.

Annette, J.: 2003, ‘Community, politics and citizenship education’, in Lockyer, A.,

Crick, B., and J. Annette’s (Eds.), Education for Democratic Citizenship, (London: Ashgate), 139-148.

Arbaugh, J.B.: 2005, ‘How much does “subject matter” matter? A study of disciplinary effects in on-line MBA courses', Academy of Management Learning \& Education 4(1), 57-73.

Beachler, C., Petri, A., Euler, M., Rinck, C., and Taylor, M.: 2006, 'Total System Integration for Academic Service-Learning: The UMKC’s SITC Experience’, International Journal of Case Method Research and Application 18(2), 157-169.

Bringle, R.G., Phillips, M.A., and Hudson, M.: 2005, The Measure of Service Learning: Research Scales to Assess Student Experiences (American Psychological Association: Washington D.C.).

Brody, S.M. and Wright, S.C.: 2004, 'Expanding the Self through Service-Learning', Michigan Journal of Community Service Learning 11(1), 14-24. 
Brower, H. H.: 2003, 'On emulating classroom discussion in a distance-delivered OBHR course: Creating an on-line community', Academy of Management Learning \& Education 2(1), 22-36.

Bushouse, B.K.: 2005, 'Community Nonprofit Organizations and Service-Learning: Resource Constraints to Building Partnerships with Universities’, Michigan Journal of Community Service Learning 12(1), 32-40.

Cavanagh, S.: 2005, 'Tokyo schools to require community service', Education Week 24(19), 11.

Clark, J.: 2001, 'Web-based teaching: A new educational paradigm’, Intercom 4, 2023.

DiPadova-Stocks, L.N. and Brown, V.L.: 2006, 'Service-Learning and the Conspiracy of Courtesy', International Journal of Case Method Research and Application 18(2), 136-147.

Dorado, S. and Giles, D.E., Jr.: 2004, 'Service-Learning Partnerships: Paths of Engagement. Michigan Journal of Community Service Learning 11(1), 25-37.

Dumas, C.: 2002, ‘Community-Based Service-Learning: Does it Have a Role in Management Education?', International Journal of Value-Based Management 15, 249-264. 
Enos, S. \& Morton, K.: 2003, 'Developing a Theory and Practice of CampusCommunity Partnerships’. In B. Jacoby \& Associates (Eds.), Building Partnerships for Service-Learning (San Francisco, CA: John Wiley \& Sons, Inc.), pp. 20-41.

Fleckenstein, M.P.: 1997, 'Service Learning in Business Ethics', Journal of Business Ethics 16, 1347-1351.

Freed, J.E.: 2005, ‘Creating a Total Quality Environment (TQE) for Learning’, Journal of Management Education 29(1), 60-81.

Fritz, J.M.: 2002, ‘A Little Bit of Sugar: Integrated Service-Learning Courses’, Sociological Practice: A Journal of Clinical and Applied Sociology 4(1), 67-77.

Galbreath, J.: 2006, ‘Are Organisation Researchers too Obsessed with the Economic Responsibility of the Firm?', Journal of Business Ethics 65: 287-295.

Godfrey, P.C.: 2000, ‘A Moral Argument for Service-Learning in Management

Education', in P.C. Godfrey and E.T. Grasso (eds.), Working for the Common Good: Concepts and Models for Service-Learning in Management Education (American Association for Higher Education, Washington, DC), pp. 21-41.

Gray, M.J., Ondaatje, E.H., and Fricker, R.D.: 2000, ‘Assessing Service-Learning: Results from a Survey of “Learn and Serve America, Higher Education”, Change 32(2), 30-39. 
Hartley, M., Harkavy, I., and Bdnson, L.: 2005, 'Putting Down Roots in the Groves of Academe: The Challenges of Institutionalizing Service-Learning', Service-Learning in Higher Education: Critical Issues and Directions (Palgrave Macmillan, New York), pp.205-222.

Kenworthy-U’Ren, A.L., and Peterson, T.O.: 2005, 'Service-Learning and Management Education: Introducing the 'WE CARE' Approach', Academy of Management Learning and Education 4(3), 272-277.

Kenworthy-U’Ren, A., Taylor, M.L., and Petri, A.: 2006, ‘Components of Successful Service-Learning Programs: Notes from Barbara Holland, Director of the U.S. National Service-Learning Clearinghouse', International Journal of Case Method Research and Application 18(2), 120-129.

Kolenko, T.A., Porter, G., Wheatley, W., and Colby, M.: 1996, ‘A Critique of Service Learning Projects in Management Education: Pedagogical Foundation, Barriers, and Guidelines’, Journal of Business Ethics 15(1), 133-142.

Kracher, B.: 1999, 'What Does it Mean When Mitchell Gets an “A” in Business Ethics? Or the Importance of Service Learning', Teaching Business Ethics 2, 291-303.

Kunkel, S.W.: 2002, 'Consultant Learning: A Model for Student-Directed Learning in Management Education', Journal of Management Education 26(2), 121-138. 
Lester, S.W., Tomkovick, C., Wells, T., and Flunker, L.: 2005, 'Does ServiceLearning Add Value? Examining the Perspectives of Multiple Stakeholders’, Academy of Management Learning and Education 4(3), 278-294.

Leung, K., Liu, W., Wang, W., and Chen, C.: 2006, 'Factors Affecting Students’ Evaluation in a Community Service-Learning Program', Advances in Health Sciences Education published online July 14, DOI: 10.1007/s10459-006-9019-1.

McCarthy, A.M.: 1996: 'One-Time and Short-Term Service-Learning Experiences’, in B. Jacoby (ed.), Service-Learning in Higher Education: Concepts and Practices (Jossey Bass: San Francisco), pp.113-134.

McCarthy, A.M. and Tucker, M.L.: 2002, ‘Encouraging Community Service Through Service-Learning', Journal of Management Education 26(6), 629-647.

Mintzberg, H. and Gosling, J.R.: 2002, ‘Reality Programming for MBAs’, Strategy and Business 26(1), 28-31.

Ngai, S.S.: 2006, 'Service-learning, personal development, and social commitment: A case study of university students in Hong Kong', Adolescence 41(161), 165-176.

Papamarcos, S.D.: 2005, ‘Giving Traction to Management Theory: Today’s ServiceLearning', Academy of Management Learning and Education 4(3): 325-335. 
Pfeffer, J., and Fong, C.T.: 2002, ‘The End of Business Schools? Less Success than Meets the Eye', Academy of Management Learning and Education 1(1), 78-95.

Poole, D.M.: 2000, 'Student participation in a discussion-oriented online course: A case study’, Journal of Research on Computing in Education 33, 162-177.

Primavera, J.: 1999, 'The Unintended Consequences of Volunteerism: Positive Outcomes for Those Who Serve', Journal of Prevention and Intervention in the Community 18(1-2), 125-140.

Ramsey, V.J.: 2002, 'Learning Journals and Learning Communities', Journal of Management Education 26(4), 380-401.

Ramsey, V.J. and Fitzgibbons, D.E.: 2005, ‘Being in the Classroom’, Journal of Management Education 29(2), 333-356.

Roos, V., Temane, Q.M., Davis, L., Prinsloo, C.E., Kritzinger, A., Naude, E. and Wessels, J.C.: 2005, ‘Service learning in a community context: learners’ perceptions of a challenging training paradigm', South African Journal of Psychology 35(4), 703716.

Roschelle, A.R., Turpin, J., and Elias, R.: 2000, ‘Who Learns From Service Learning?’, American Behavioral Scientist 43(5), 839-847. 
Ryan, A.: 1997, John Dewey and the High Tide of American Liberalism. (New York, NY: W.W. Norton).

Shea-Schultz, H. and Fogerty, J.: 2002, Online learning today: Strategies that work. (San Francisco, CA: Berrett-Koehler).

Sternberger, L.G., Ford, K.A., and Hale, D.C. 2005, 'International service-learning: Integrating academics and active learning in the world', Journal of Public Affairs 8 , 75-96.

Taylor, J.A.: 2003, ‘Managing staff development for online education: A situated learning model', Journal of Higher Education Policy and Management 25(1), 76-87.

Van der Voort, J.M., Meijs, L.C., and Whiteman, G. 2005, ‘Creating actionable knowledge: Practicing service-learning in a Dutch business school context', Educating Managers through Real World Projects (Charlotte, NC: Information Age), 149-180.

Vega, G. and McHugh, M.A.: 2003, ‘’What Button Do I Press?” The Consequences of Conducting a Service Learning Project with Senior Citizens', Journal of Academic Ethics 1, 97-117.

Weber, J.: 2006, 'Implementing an Organizational Ethics Program in an Academic Environment: The Challenges and Opportunities for the Duquesne University Schools of Business', Journal of Business Ethics 65: 23-42. 
A Decade of Service-learning

Wheeler, J.V. and McLeod, P.L.: 2002, ‘Expanding Our Teaching Effectiveness:

Understanding Our Responses to “In-The-Moment” Classroom Events’, Journal of Management Education 26(6), 693-716.

Wittmer, D.P.: 2004, 'Business and Community: Integrating Service Learning in Graduate Business Education”, Journal of Business Ethics 51, 359-371. 